\title{
Functional proteomics and correlated signaling pathway of the thermophilic bacterium Bacillus stearothermophilus TLS33 under cold-shock stress
}

\author{
Supachai Topanurak ${ }^{1,2}$, Supachok Sinchaikul ${ }^{1}$, Boonyaras Sookkheo ${ }^{3}$, \\ Suree Phutrakul ${ }^{2}$ and Shui-Tein Chen ${ }^{1,4}$ \\ ${ }^{1}$ Institute of Biological Chemistry and Genomics Research Center, Academia Sinica, Taipei, Taiwan \\ ${ }^{2}$ Department of Chemistry, Faculty of Science, Chiang Mai University, Chiang Mai, Thailand \\ ${ }^{3}$ Department of Chemistry, Faculty of Science, Rangsit University, Pathumthani, Thailand \\ ${ }^{4}$ Institute of Biochemical Sciences, College of Life Science, National Taiwan University, Taipei, Taiwan
}

\begin{abstract}
The thermophilic bacterium Bacillus stearothermophilus TLS33 was examined under cold-shock stress by a proteomic approach to gain a better understanding of the protein synthesis and complex regulatory pathways of bacterial adaptation. After downshift in the temperature from $65^{\circ} \mathrm{C}$, the optimal growth temperature for this bacterium, to $37^{\circ} \mathrm{C}$ and $25^{\circ} \mathrm{C}$ for $2 \mathrm{~h}$, we used the highthroughput techniques of proteomic analysis combining 2-DE and MS to identify 53 individual proteins including differentially expressed proteins. The bioinformatics database was used to search the biological functions of proteins and correlate these with gene homology and metabolic pathways in cell protection and adaptation. Eight cold-shock-induced proteins were shown to have markedly different protein expression: glucosyltransferase, anti-sigma $B\left(\sigma^{B}\right)$ factor, Mrp protein homolog, dihydroorthase, hypothetical transcriptional regulator in FeuA-SigW intergenic region, RibT protein, phosphoadenosine phosphosulfate reductase and prespore-specific transcriptional activator RsfA. Interestingly, six of these cold-shock-induced proteins are correlated with the signal transduction pathway of bacterial sporulation. This study aims to provide a better understanding of the functional adaptation of this bacterium to environmental cold-shock stress.
\end{abstract}

\section{Keywords:}

Bacillus stearothermophilus / Cold-shock / Signaling pathway / Sporulation / Thermophile

\section{Introduction}

Prokaryotic microorganisms can be classified according to their temperature ranges of growth. Thermophiles are heatloving microorganisms with an optimum growth above $50^{\circ} \mathrm{C}$, whereas mesophiles grow between $10^{\circ} \mathrm{C}$ and $50^{\circ} \mathrm{C}$ [1]. Psychrophiles and psychrotrophs grow at or near $0^{\circ} \mathrm{C}$ but are

Correspondence: Dr. Shui-Tein Chen, Institute of Biological Chemistry (RM707), Academia Sinica, 128 Yen Chiu Yuan Rd., Sec. II, Nankang, Taipei, 11529, Taiwan

E-mail: bcchen@gate.sinica.edu.tw

Fax: +886-2-27883473
Received: March 1, 2004

Revised: January 6, 2005

Accepted: January 16, 2005 differentiated by their optimal and maximal growth temperatures. Despite their differences, common physiological changes occur within all these microorganisms in response to temperature change [1-3]. Study of the cold-shock response is important for understanding cell growth at, or cell tolerance to, low temperature. A downshift in temperature causes a transient induction of a large number of proteins, termed cold-induced proteins (CIPs), but also repression of many proteins that are synthesized under normal condition [4]. Some of these cold-induced proteins are essential for various levels of cellular physiology including metabolism, transcription, translation and protein folding [5, 6]. The most extensive studies on low-temperature adaptation of prokar- 
yotes have been conducted with E. coli [7-12] and B. subtilis [13-16]. Adaptation and protein expression in response to cold-shock stress has been investigated for several bacteria, such as B. caldolyticus [17], B. caldotenex [18], Helicobacter pylori [19], Mycoplasma genitalium [19], Thermotoga maritime [20], and B. stearothermophilus [21, 22]. Proteomic analysis combining 2-DE, MS and bioinformatics is a powerful approach for studying the alteration of protein expression in organisms under different environmental conditions. These techniques have also been applied to explore structures or functions of specific proteins from microorganisms in sequenced genomes, such as E. coli [23, 24], B. subtilis [25, 26], and Saccharomyces cerevisiae [27].

In this study, we used a proteomic approach combining 2-DE and MS to analyze the differentially expressed proteins of the thermophilic bacterium B. stearothermophilus TLS33 under cold-shock stress. After downshift in the temperature from the optimal growth temperature at $65^{\circ} \mathrm{C}$ to $37^{\circ} \mathrm{C}$ and $25^{\circ} \mathrm{C}$, 2-DE results showed the differential protein expressions at these three temperatures, and image analysis software was used to compare the protein spots on 2-D images and to detect the spots representing differentially expressed protein. We identified a number of protein spots that were differentially expressed when the bacterium encountered in the cold-shock environment. We then used the bioinformatics database to search for protein and gene correlation, biological functions and the relationship of the proteins in signaling pathway of sporulation. Interestingly, we found that eight cold-shock-induced proteins, which differ from those in B. subtilis and E. coli, play an important role in cell adaptation under cold-shock stress. Moreover, we suggest a model of sigma $(\sigma)$ signal transduction network correlated with the observed cold-shock-induced proteins in an attempt to further understand the bacterial adaptation under coldshock stress.

\section{Materials and methods}

\subsection{Bacterial growth and cold-shock experiment}

The thermophilic bacterium B. stearothermophilus TLS33 was isolated from soil at hot springs in Chiang Mai, Thailand. The bacteria were cultured in $50 \mathrm{~mL}$ media containing $0.1 \%$ yeast extract, $0.1 \%$ tryptone and $0.1 \%$ base mixture $\mathrm{pH} 7.2$ $\left(0.8 \mathrm{~g} / \mathrm{L}\right.$ Titriplex I, $0.36 \mathrm{~g} / \mathrm{L} \mathrm{CaSO}_{4} \cdot 2 \mathrm{H}_{2} \mathrm{O}, 1 \mathrm{~g} / \mathrm{L} \mathrm{MgCl}_{2} \cdot 6 \mathrm{H}_{2} \mathrm{O}$, $0.2 \mathrm{~g} / \mathrm{L} \mathrm{NaOH}$ and $4 \mathrm{~mL} 0.01 \mathrm{M}$ iron III citrate) [28]. The cultures were incubated in a water bath at $65^{\circ} \mathrm{C}$ with shaking at $200 \mathrm{rpm}$ (in triplicate for each experiment). After reaching an $\mathrm{OD}_{620}$ of 0.5 (the mid-log phase of this bacterium), coldshock was initiated by transferring the culture flasks to the water baths at $37^{\circ} \mathrm{C}$ or $25^{\circ} \mathrm{C}$. The cell growth profile under cold-shock stress was examined for up to $8 \mathrm{~h}$. For all analytical procedures, the cells cultured $65^{\circ} \mathrm{C}$ (control), $37^{\circ} \mathrm{C}$ and $25^{\circ} \mathrm{C}$ were harvested by centrifugation at $12000 \times \mathrm{g}$ at $4^{\circ} \mathrm{C}$ for $30 \mathrm{~min}$.

\subsection{Sample preparation}

Cell pellets were resuspended in TE buffer, containing $20 \mathrm{~mm}$ Tris- $\mathrm{HCl} \mathrm{pH} 8.0$ and $10 \mathrm{~mm}$ EDTA, and disrupted on ice by sonication (five cycles of $45 \mathrm{~s}$ ). Cell debris was removed by centrifugation at $12000 \times \mathrm{g}$ at $4^{\circ} \mathrm{C}$ for $20 \mathrm{~min}$. The sample solutions were precipitated by addition of $10 \%$ TCA and $0.1 \%$ DTT and stored overnight at $-20^{\circ} \mathrm{C}$ to precipitate the proteins and to remove the salt and nucleic acid. The suspension was centrifuged at $20000 \times \mathrm{g}$ for $30 \mathrm{~min}$. Protein pellets were resuspended in ice-cold acetone containing $0.1 \%$ DTT and stored at $-20^{\circ} \mathrm{C}$ for at least $30 \mathrm{~min}$. The protein suspension was centrifuged again at $20000 \times$ g for $30 \mathrm{~min}$ and the pellets were resuspended in ice-cold acetone without DTT. The protein suspension was stored at $-20^{\circ} \mathrm{C}$ for $30 \mathrm{~min}$ and then centrifuged at $20000 \times \mathrm{g}$ for $30 \mathrm{~min}$. The obtained pellets were immediately dissolved in lysis buffer $(7 \mathrm{~m}$ urea, $2 \mathrm{~m}$ thiourea, 4\% CHAPS, 1\% IPG buffer $\mathrm{pH} 4-7$ and $65 \mathrm{~mm}$ DTT) [29]. Each sample was sonicated and centrifuged, and the protein concentration was determined using a PlusOne ${ }^{\mathrm{TM}}$ 2-D Quant Kit (Amersham Biosciences, Uppsala, Sweden) with bovine albumin (BSA) as a standard.

\subsection{2-DE analysis}

Each sample was applied onto IPG strips $(18 \mathrm{~cm}, \mathrm{pH} 4-7 \mathrm{~L}$; Amersham Biosciences) with a final concentration of $100 \mu \mathrm{g}$ protein in $350 \mu \mathrm{L}$. IPGphor IEF (Amersham Biosciences) was performed under following condition: IPG strips were rehydrated passively and/or actively for $12 \mathrm{~h}$ at $30 \mathrm{~V}$ followed by ramping to $250 \mathrm{~V}$ for $1 \mathrm{~h}, 500 \mathrm{~V}$ for $1 \mathrm{~h}, 1000 \mathrm{~V}$ for $1 \mathrm{~h}$, $3500 \mathrm{~V}$ for $3 \mathrm{~h}$, and focusing at $8000 \mathrm{~V}$ for up to $7.5 \mathrm{~h}$. After IEF, the IPG strips were equilibrated in equilibration buffer I (50 mm Tris-HCl pH 8.8, 6 м urea, 30\% glycerol, 2\% SDS, 2\% DTT and a trace of bromophenol blue) for $15 \mathrm{~min}$, and then subsequently alkylated in equilibration buffer II (50 mM Tris$\mathrm{HCl} \mathrm{pH} \mathrm{8.8,} 6 \mathrm{~m}$ urea, 30\% glycerol, 2\% SDS, 2.5\% w/v iodoacetamide and a trace of bromophenol blue) for $15 \mathrm{~min}$. Each equilibrated IPG strip was placed on top of the linear gradient of $10-20 \%$ polyacrylamide gel $(185 \times 200 \times 1.5 \mathrm{~mm})$ and covered with $0.5 \%$ agarose. The second-dimensional separation was performed using the Protean xi Multi-Cells (Bio-Rad) and carried out at $45 \mathrm{~mA}$ per gel at $15^{\circ} \mathrm{C}$ until the bromophenol blue dye front reached the bottom of the gel. At the end of each run, the 2-D gels were fixed in $10 \%$ methanol/7\% acetic acid for $30 \mathrm{~min}$ and subsequently stained using the SYPRO Ruby method [30]. The stained gels were scanned using a Typhoon 9200 image scanner (Amersham Biosciences).

\subsection{Comparative image analysis}

The statistical data (spot detection, spot editing, pattern matching, up- and down-regulations) were acquired and analyzed using the ImageMaster 2D elite software package (Amersham Biosciences) with a high image quality TIF for- 
mat (600 dpi). Statistical analyses were performed in triplicate of three gels from each experimental growth condition to determine spots showing reproducible changes. For gel-to-gel comparison, the 2-D image of cell at $65^{\circ} \mathrm{C}$ was set as the reference gel image. Before matching the images, background was subtracted (using the lowest-on-boundary method) and normalization was performed to correct for the differences in protein spot intensity. The reference gel image was matched to another gel image, and the matching was manually edited to ensure correct spot matches and to ensure more consistent determination of spot volume. Matched spot data (spot number and volume) was exported to an Excel table (Microsoft) for calculation of spot volume and construction of graphs to compare protein expression. The quantification of each spot was expressed as percent volume, where $\% \mathrm{~V}=$ spot volume/ volumes of all spots resolved in the gels.

\subsection{Protein digestion}

Protein spots were manually excised from the polyacrylamide gels and transferred to $500-\mu \mathrm{L}$ siliconized Eppendorf tubes. The gel pieces were washed twice with $200 \mu \mathrm{L} 50 \%$ ACN/25 mM ammonium bicarbonate buffer pH 8.0 for $15 \mathrm{~min}$ each. The gel pieces were then washed once with $200 \mu \mathrm{L} \mathrm{100 \%} \mathrm{ACN} \mathrm{and} \mathrm{dried} \mathrm{using} \mathrm{a} \mathrm{SpeedVac} \mathrm{concentrator.}$ Dried gel pieces were swollen in $10 \mu \mathrm{L} 25 \mathrm{~mm}$ ammonium bicarbonate containing $0.1 \mu \mathrm{g}$ trypsin (sequencing grade; Promega, Madison, WI, USA). Gel pieces were then crushed with a siliconized blue stick and incubated at $37^{\circ} \mathrm{C}$ for at least $16 \mathrm{~h}$. Peptides were subsequently extracted twice with $50 \mu \mathrm{L}$ $50 \% \mathrm{ACN} / 5 \% \mathrm{TFA}$, and the extracted solutions were combined and dried using SpeedVac concentrator. The peptides or pellets were then resuspended in $20 \mu \mathrm{L} 0.1 \%$ TFA and the suspended solutions were purified using ZipTip C18 (Millipore, Bedford, MA, USA). Briefly, $10 \mu \mathrm{L}$ sample was drawn up and down in the ZipTip ten times, and the ZipTip was washed with $10 \mu \mathrm{L} 0.1 \%$ formic acid by drawing up and expelling the washing solution three times. The peptides were eluted with $5 \mu \mathrm{L} 75 \%$ ACN/0.1\% formic acid.

\subsection{MALDI-MS analysis}

The samples were mixed in a ratio of $1: 1$ with matrix solution ( $5 \mathrm{mg} / \mathrm{mL}$ CHCA in 50\% ACN, $0.1 \%$ TFA and $2 \%$ ammonium citrate) and spotted onto the 96-well plate of a PerSeptive Biosystems Voyager DE-RP MALDI-TOF mass spectrometer (PerSeptive Biosystems, Framingham, MA, USA). Adrenocorticotropic hormone (ACTH), 1 pmol/ $\mu \mathrm{L}$, was used as an external calibration. MS analysis was performed using an acceleration voltage of $20 \mathrm{kV}$ [31]. PMF spectra obtained from each digested protein were searched against protein PMF databases via the programs Protein Prospector MS-FIT (http://prospector.ucsf.edu/ucsfhtml4.0/msfit.htm) and MASCOT (http://www.matrixscience.com). Search parameters allowed for oxidation of methionine, carbamidomethylation of cysteine, one missed trypsin cleavage, and $50 \mathrm{ppm}$ mass accuracy. Peptides in the mass range of 1000-3500 Da were selectively searched in the database. The remaining autodigestion trypsin and keratin peaks were removed from the mass list before database searching. Protein identification was repeated at least once more using spots from different gels.

\subsection{Bioinformatics for functional properties}

The SubtiList (http://genolist.pasteur.fr/SubtiList) supplementing with EMBL/GenBank/DDBJ databanks, COGs (http://www.ncbi.nlm.nih.gov/COG), Swiss-Prot (http:// us.expasy.org/sprot), TrEMBL (http://www.expasy.ch/sprot) and Micado (http://www-mig.jouy.inra.fr/bdsi/Micado) were searched for sequence homology and biological functions corresponding to identified proteins. In addition, the DIP database (http://dip.doe-mbi.ucla.edu) was used for determining protein-protein interactions.

\section{Results and discussion}

\subsection{Growth profile of B. stearothermophilus TLS33 under cold-shock}

To investigate transient metabolic adaptation for bacterial survival and its physiological activity, the proteome of thermophile B. stearothermophilus TLS33 under cold-shock stress was studied immediately after transferring the bacterial cultures from their optimal growth temperature at $65^{\circ} \mathrm{C}$ to $37^{\circ} \mathrm{C}$ or $25^{\circ} \mathrm{C}$, which represent the temperature of normal bacterial growth temperature and room temperature, respectively. The growth profile of this bacterium is shown in Fig. 1. We chose the mid-log phase of the bacterial growth at $24 \mathrm{~h}\left(\mathrm{OD}_{620} \sim 0.5\right.$, $\mathrm{T}=0 \mathrm{~h}$ ) for cold-shock experiment because at this time

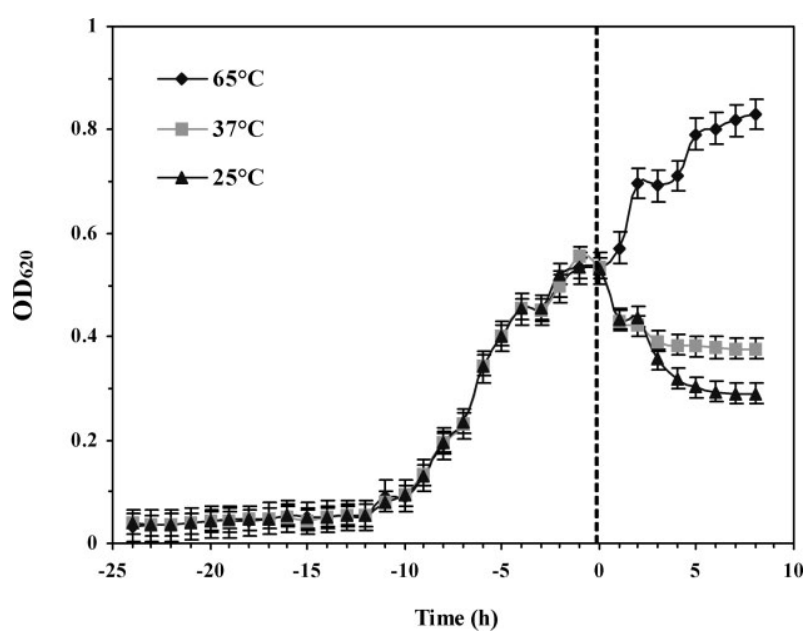

Figure 1. Growth profile of $B$. stearothermophilus TLS33 under cold-shock stress at $37^{\circ} \mathrm{C}$ and $25^{\circ} \mathrm{C}$ cultured for $32 \mathrm{~h}$. Cold-shock stress was induced after the $24 \mathrm{~h}$ of culture $(\mathrm{T}=0 \mathrm{~h}$, starting time of cold-shock stress) for $8 \mathrm{~h}(\mathrm{~T}=8 \mathrm{~h})$. 
bacterial cells begin to synthesize differential proteins and other components, such as primary and secondary metabolites, leading to more resistance to the non-optimal environmental conditions. Within the first $2 \mathrm{~h}$ after cold-shock at $37^{\circ} \mathrm{C}$ or $25^{\circ} \mathrm{C}$, the bacterial growth rate decreased, and reached a constant rate by $4 \mathrm{~h}$. In contrast, bacterial growth at $65^{\circ} \mathrm{C}$ increased over the 8 - $\mathrm{h}$ period $(\mathrm{T}=+8 \mathrm{~h})$. Thus, $2 \mathrm{~h}$ after cold shock was considered the appropriate time point for proteomic analysis of this bacterium response to cold-shock stress in this study. We investigated a large number of proteins for which the synthesis and expression levels were changed after cold-shock, including those involved in bacterial adaptation to cold-shock stress and sporulation [28, 32-35].

\subsection{2-DE analysis}

The cell extracts obtained after a temperature downshift from $65^{\circ} \mathrm{C}$ to $37^{\circ} \mathrm{C}$ or $25^{\circ} \mathrm{C}$ for $2 \mathrm{~h}$ or after incubation at $65^{\circ} \mathrm{C}$ for $2 \mathrm{~h}$ (control) (all performed in triplicate) showed reproducible 2-D gel patterns, analysis of which demonstrated the differential protein synthesis of this bacterium under coldshock stress (Fig. 2). The protein pattern at $65^{\circ} \mathrm{C}$ showed a number of proteins within a narrow $\mathrm{p} I$ range of 4-7 and with molecular mass of more than $25 \mathrm{kDa}$, while the protein patterns at $37^{\circ} \mathrm{C}$ and $25^{\circ} \mathrm{C}$ showed fewer proteins. Few proteins with a $\mathrm{p} I$ in the range 3-4 or 7-11 were observed in any cell extract from any of the experimental temperatures. Thus, we focused our analysis on the proteins in the narrow $\mathrm{p} I$ range of 4-7, similar to other reports showing that a number of proteins in $B$. subtilis were restricted to a rather narrow $\mathrm{p} I$ range of 4-7 and a molecular mass range of 5-100 kDa [3537]. Moreover, the 2-D gel patterns were shown to have a low resolution of protein separation, leading to a low yield of proteins. This may be caused by the low solubility of intracellular proteins from thermophilic cells, which may be due to (1) the high residue hydrophobicity and more charged amino acids, especially Glu, Arg and Lys, necessary to conserve its protein function in high temperature, and (2) the proteins in the cell extracts were precipitated by TCA, which may have resulted in protein aggregation due to the low $\mathrm{pH}$ and difficulty with resolubilizing protein precipitate completely. However, we attempted to resuspend the precipitated proteins in lysis buffer homogeneously prior to protein analysis using 2-DE. Although the protein distributions at the three different temperatures appeared similar on 2-D gel patterns, the exact number of protein spot for each temperature were compared on triplicate 2-D gels and quantitated using ImageMaster 2D elite software. The total number of protein spots on 2-D gels detected after culture at $65^{\circ} \mathrm{C}$, and after cold shock at $37^{\circ} \mathrm{C}$ and $25^{\circ} \mathrm{C}$ were 191,116 and 115 , respectively. The pair-wise comparisons of protein spots from the different temperature groups: (1) $37^{\circ} \mathrm{C}$ and $65^{\circ} \mathrm{C}$, (2) $25^{\circ} \mathrm{C}$ and $65^{\circ} \mathrm{C}$, and $(3) 37^{\circ} \mathrm{C}$ and $25^{\circ} \mathrm{C}$, showed the matched proteins of 66,57 and 75 spots with $34.55 \%, 29.84 \%$ and 64.65\% matching, respectively. A twofold increase or decrease in protein synthesis of the differentially expressed
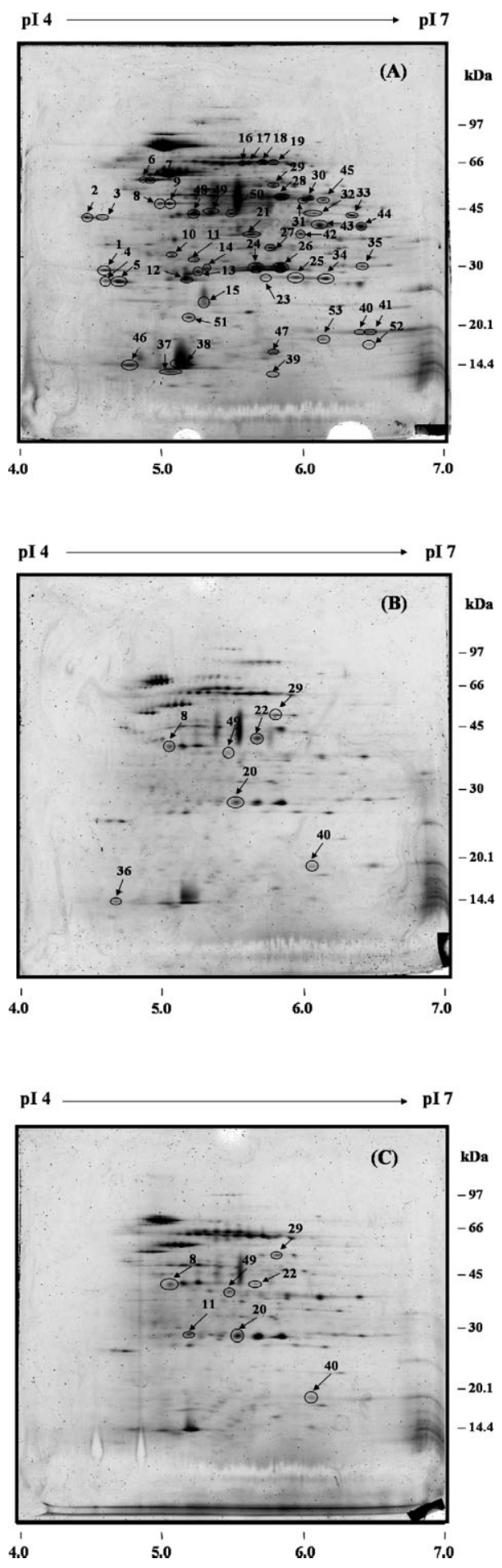

Figure 2. 2-D gel images of cell extracts from $B$. stearothermophilus TLS33 at three different temperatures; (A) $65^{\circ} \mathrm{C}$, (B) $37^{\circ} \mathrm{C},(\mathrm{C}) 25^{\circ} \mathrm{C}$. The arrows show the spots of proteins, which were identified by MALDI-TOF MS.

protein under cold-shock stress was classified as up-regulation or down-regulation, respectively. The pair-wise comparisons of the proteins in the different temperature groups 1-3, 
(A)

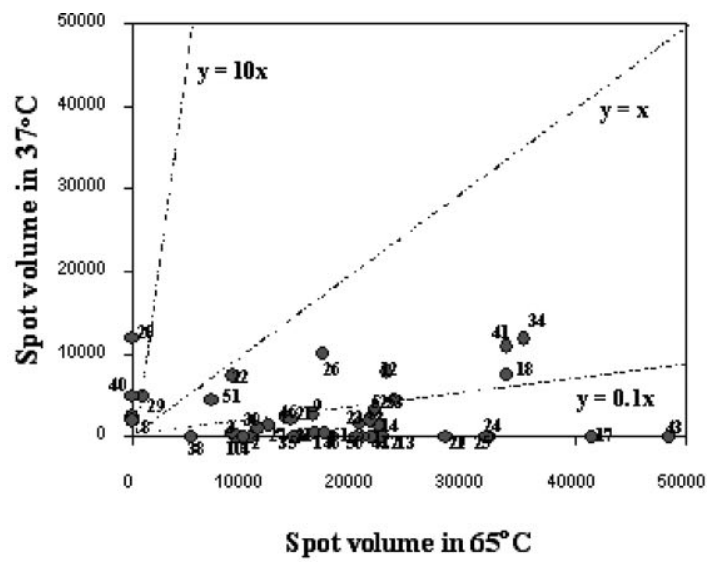

(B)

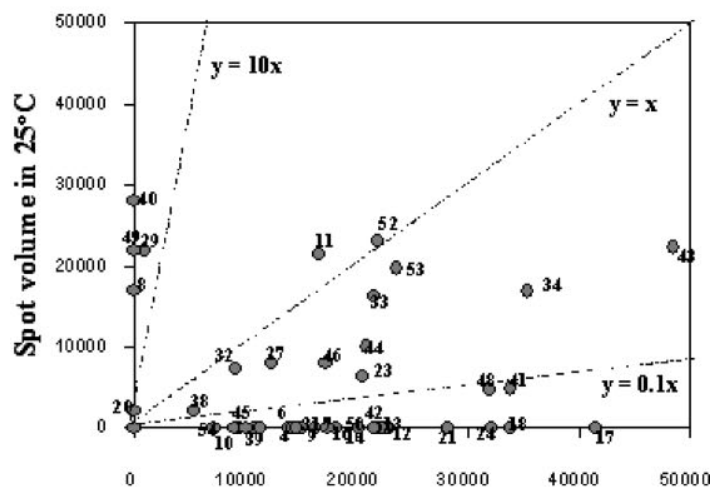

Sp ot volume in $65^{\circ} \mathrm{C}$

(C)

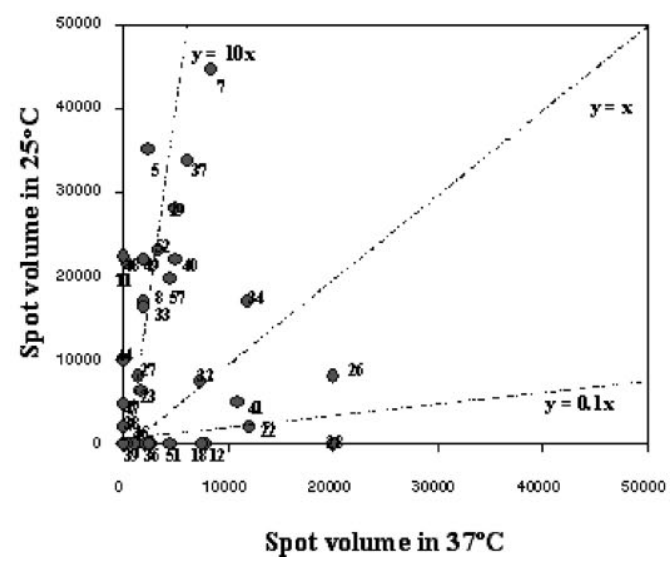

Figure 3. The increase and decrease of protein levels from $B$. stearothermophilus TLS33 after temperature downshift from $65^{\circ} \mathrm{C}$ to $37^{\circ} \mathrm{C}$ and to $25^{\circ} \mathrm{C}$, demonstrated using ImageMaster $2 \mathrm{D}$ Elite software. (A) Comparison between the temperatures at $37^{\circ} \mathrm{C}$ and $65^{\circ} \mathrm{C}$; (B) comparison between the temperatures at $25^{\circ} \mathrm{C}$ and $65^{\circ} \mathrm{C}$; (C) comparison between the temperatures at $25^{\circ} \mathrm{C}$ and $37^{\circ} \mathrm{C}$.

as mentioned above, showed 44, 25 and 10 up-regulated proteins, and 20, 29 and 12 down-regulated proteins, respectively. Furthermore, the differential protein levels were also evaluated using a linear scatter plot, in which $y=10 x$ (up- regulation or increase of protein abundance), $y=x$ (equal) and $y=0.1 x$ (down-regulation or decrease of protein abundance), as shown in Fig. 3A-C. Fifty-three intracellular proteins were detected in the cells of this thermophilic bacterium at these three temperatures and these might represent the housekeeping proteins. Interestingly, only eight major cold-shock-induced proteins were markedly changed by the cold-shock stress.

\subsection{Protein identification and differential protein synthesis}

Individual protein spots were excised from the 2-D gels, subjected to in-gel digestion and analyzed by MALDI-TOF MS. A total of 53 intracellular proteins were recognized on the basis of the tryptic mass profile comparisons using the SwissProt and NCBI non-redundant database with MS-FIT and MASCOT software (Table 1). In addition, the SubtiList database (http://genolist.pasteur.fr/SubtiList) and EMBL/ GenBank/DDBJ databases were used to determine the correlations at the genome level, accession numbers, description and functional categories of the identified proteins (Table 2). Moreover, the intracellular proteins from B. stearothermophilus TLS33 were compared with the complete genomes of $B$. subtilis and B. halodurans based on the COG (Clusters of Orthologous Groups of protein) database using the COGNITOR program (http://www.ncbi.nlm.nih.gov/ COG), which represents a phylogenetic classification in functional annotation (Table 3). The results of the database search showed that most of intracellular proteins from $B$. stearothermophilus TLS33 had biological functions related to cellular process and metabolism, indicating the adaptation or maintenance of this bacterium under cold-shock stress. We found that eight cold-shock-induced proteins had markedly changed at the different temperatures: glucosyltransferase, anti-sigma B $\left(\sigma^{\mathrm{B}}\right)$ factor (RsbT), Mrp protein homolog, dihydroorthase, hypothetical transcriptional regulator in the FeuA-SigW intergenic region, RibT protein, phosphoadenosine phosphosulfate reductase, and prespore-specific transcriptional activator. Only glucosyltransferase, Mrp protein homolog, dihydroorthase, RibT protein, phosphoadenosine phosphosulfate reductase, and prespore-specific transcriptional activator were observed at $37^{\circ} \mathrm{C}$ and $25^{\circ} \mathrm{C}$. Using Image Master 2D Elite software, we also classified the major coldshock-induced proteins into three groups, depending on the protein synthesis level at different temperatures (Fig. 4). The first group of the protein synthesis at $37^{\circ} \mathrm{C}$ and $25^{\circ} \mathrm{C}$ comprised glucosyltransferase, Mrp protein homolog, dihydroorthase, phosphoadenosine phosphosulfate reductase, and prespore-specific transcriptional activator RsfA. The second group of the protein synthesis at only $37^{\circ} \mathrm{C}$ comprised RibT protein. The last group of the protein synthesis at $65^{\circ} \mathrm{C}$ and $25^{\circ} \mathrm{C}$ comprised anti- $\sigma^{\mathrm{B}}$ factor (RsbT) and the hypothetical transcriptional regulator in FeuA-SigW intergenic region. In addition, the cold-shock-induced proteins at $37^{\circ} \mathrm{C}$ were Mrp protein homolog, dihydroorthase and RibT pro- 
Table 1. Protein identification of intracellular proteins in B. stearothermophilus TLS33, after temperature downshift to $37^{\circ} \mathrm{C}$ and $25^{\circ} \mathrm{C}$, by MS-FIT and MASCOT software, based on Swiss-Prot database (http://www.expasy.ch/sprot)

\begin{tabular}{|c|c|c|c|c|c|}
\hline $\begin{array}{l}\text { Spot } \\
\text { no. }\end{array}$ & Protein name & $\begin{array}{l}\text { Acces- } \\
\text { sion no. }\end{array}$ & $\begin{array}{l}\text { Mol. mass } \\
\text { (Da)/ pl }\end{array}$ & $\begin{array}{l}\text { No. peptide } \\
\text { matched }\end{array}$ & 4 sample matched peptides \\
\hline 1 & $\begin{array}{l}\text { Pts system, fructose-specific IIB component } \\
\text { (EIIB-FRU) (Fructose-permease } \\
\text { IIB component) (Phosphotransferase } \\
\text { enzyme II, B component) (P18) (PTFB) }\end{array}$ & P26380 & 35051 / 4.37 & 9 & $\begin{array}{l}\text { MMNIVLAR IDDRFIHGQILTRWIK VHAA- } \\
\text { DRIIVVSDDIAODEMR KTLILSVAPSNVK }\end{array}$ \\
\hline 2 & Stage III sporulation protein AE (S3AE) & P49782 & $39191 / 4.55$ & 7 & $\begin{array}{l}\text { TAASLETDK IGEFWNDIMTEYGGLLPESOK GSLME- } \\
\text { FINGDK SFSPOEWLK }\end{array}$ \\
\hline 3 & $\begin{array}{l}\text { Inosine-5'-monophosphate dehydrogenase } \\
\text { (IMP dehydrogenase) (IMPDH) (IMPD) } \\
\text { (Superoxide-inducible protein 12, SOI12) } \\
\text { (IMDH) }\end{array}$ & P21879 & $39191 / 4.62$ & 12 & $\begin{array}{l}\text { DVDLSVELTKTLK GVITNPFFLTPDHOVFDAEHLMGK } \\
\text { SGVPIVNNEEDOK LVGIITNRDLRFISDYSMK }\end{array}$ \\
\hline 4 & COMF operon protein 3 (CMF2) & P39147 & $29901 / 4.76$ & 9 & $\begin{array}{l}\text { ALFLLKPDEK VCYSCRSKLK EVWRTRIR } \\
\text { SDFSSTFSKVYPDK }\end{array}$ \\
\hline 5 & Unknown protein & - & $28100 / 4.64$ & - & \\
\hline 6 & Flagellar protein (FLIT) & P39740 & $58100 / 4.64$ & 14 & $\begin{array}{l}\text { SMLSHIONTPESDELLK SIATELOOMKR } \\
\text { RVMHTTYLNPYNNITIDGTYYDKR OSIA- } \\
\text { TELOOMKRKR }\end{array}$ \\
\hline 7 & $\begin{array}{l}\text { DNA topoisomerase I (Omega-protein) } \\
\text { (Relaxing enzyme) (Untwisting enzyme, } \\
\text { Swivelase) (TOP1) }\end{array}$ & P39814 & $58250 / 4.55$ & 26 & $\begin{array}{l}\text { TIERYLGKKYK SOMGVDIEONFEPK } \\
\text { NPALPFTTSTLOOEAARK EGTVGLITYMR }\end{array}$ \\
\hline 8 & $\begin{array}{l}\text { Probable poly (glycerol-phosphate) alpha- } \\
\text { glucosyltransferase (Teichoic acid } \\
\text { biosynthesis protein) (TAGE) }\end{array}$ & P13484 & $48700 / 4.44$ & 18 & $\begin{array}{l}\text { QIPDMDYYFISGGLPSNYGGLTK } \\
\text { LFGEECNQNTFFLTFR NNEMSVYYGDGETIR } \\
\text { MYLOEYINDQNQVYLDK }\end{array}$ \\
\hline 9 & Translation initiation factor (IF-2) & P17889 & $48100 / 4.64$ & 29 & $\begin{array}{l}\text { NMDLEVNNHMAMLEEK VVEGE- } \\
\text { AGGITOHIGAYOIEENGK ITFLDTPGHAAFTTM- } \\
\text { RAR AAEVPIIVAVNK }\end{array}$ \\
\hline 10 & $\begin{array}{l}\text { Putative peptidase in gcvT-spollIAA } \\
\text { intergenic region (YOHT) }\end{array}$ & P54518 & $36067 / 5.10$ & 12 & $\begin{array}{l}\text { YMTGFTGSAGLAVISGDK SSLPHGVASDK } \\
\text { TVAVGQPSDQLK EIYQVVFDAOALGVA- } \\
\text { HIKPGMTGK }\end{array}$ \\
\hline 11 & Anti-sigma B factor (RSBT) & P42411 & $34803 / 5.14$ & 10 & $\begin{array}{l}\text { MNDQSCVR IMTEWDIVAAR ELGFGTVDQAR IT- } \\
\text { TAISELAR OLGR }\end{array}$ \\
\hline 12 & $\begin{array}{l}\text { Extragenic suppressor protein suhB } \\
\text { homolog (SUHB) }\end{array}$ & 045499 & $31533 / 5.20$ & 11 & $\begin{array}{l}\text { KWIREAGAR ITQSMHESLTIETK SNPNDLVTNIDK } \\
\text { NFAISIGIFENGEGK }\end{array}$ \\
\hline 13 & Unknown protein & - & $33103 / 5.30$ & - & \\
\hline 14 & $\begin{array}{l}\text { Hypothetical 28.6-kDa protein in rec } 0 \text {-cmk } \\
\text { intergenic region precursor (YPBG) }\end{array}$ & P50733 & 34187 / 5.53 & 9 & $\begin{array}{l}\text { MYATAKGNHLK THTFPLSKMK } \\
\text { LVHFGVPIVFVWGNNDYEVR NAAYLISNGYGTTK }\end{array}$ \\
\hline 15 & Unknown protein & - & $24187 / 5.53$ & - & \\
\hline 16 & GTP-binding protein (LEPA) & P37949 & $69284 / 5.49$ & 26 & $\begin{array}{l}\text { NFSIIAHIDHGK EQLLDSMDLER OEVEDVIGLDA- } \\
\text { SEAVLASAK VPAPTGDPEAPLK }\end{array}$ \\
\hline 17 & $\begin{array}{l}\text { 2,3-Bisphosphoglycerate-independent } \\
\text { phosphoglycerate mutase } \\
\text { (BPG-independent pgaM) (LEPA) }\end{array}$ & P39773 & 69284 / 5.61 & 12 & $\begin{array}{l}\text { NETVGNAVALAK AIQISNTFTNKDFR TYINQLNDQIK } \\
\text { SALDVVDDSYANGIYDEFVIPSVITK }\end{array}$ \\
\hline 18 & Unknown protein & - & 69486 / 5.72 & - & - \\
\hline 19 & $\begin{array}{l}\text { Peptide methionine sulfoxide reductase } \\
\text { (Protein-methionine-s-0xide reductase) } \\
\text { (Peptide met (0) reductase) (MSRA) }\end{array}$ & P54154 & 69284 / 5.81 & 10 & $\begin{array}{l}\text { EIATFAGGCFWCMVKPFDEQPGIEK VVSGYTGGH- } \\
\text { TENPTYEEVCSETTGHR AEPFYEAEGYHOHFYK } \\
\text { NPAHYQRYRTGSGR }\end{array}$ \\
\hline 20 & MRP protein homolog (MRP) & P50863 & $28628 / 5.55$ & 11 & $\begin{array}{l}\text { ALERVGVPYFVSEKPEELK EADA- } \\
\text { FILPGVGSFGDAMDNLGYTK GKAVRLKAE- } \\
\text { DEKGNKLK EPFLORPLGELDAVK }\end{array}$ \\
\hline
\end{tabular}


Table 1. Continued

\begin{tabular}{|c|c|c|c|c|c|}
\hline $\begin{array}{l}\text { Spot } \\
\text { no. }\end{array}$ & Protein name & $\begin{array}{l}\text { Acces- } \\
\text { sion no. }\end{array}$ & $\begin{array}{l}\text { Mol. mass } \\
(\mathrm{Da}) / \mathrm{p} /\end{array}$ & $\begin{array}{l}\text { No. peptide } \\
\text { matched }\end{array}$ & 4 sample matched peptides \\
\hline 21 & $\begin{array}{l}\text { Hypothetical 58.2-kDa protein in kdgT-xpt } \\
\text { intergenic region (YPWA) }\end{array}$ & P50848 & 38614 / 5.59 & 12 & $\begin{array}{l}\text { TGAPK ELIDVLYER ELSLYFLOELGYDFDGGR AIFS- } \\
\text { NEVSVEDLPSLWNOK }\end{array}$ \\
\hline 22 & Dihydroorotase (Dhoase) (PYRC) & P25995 & 39144 / 5.66 & 14 & $\begin{array}{l}\text { NGWILNENGEK VTGETITAIGK LDATDNETVIDAK } \\
\text { GGYTTVAAMPNTRPVPDTK }\end{array}$ \\
\hline 23 & $\begin{array}{l}\text { Transcription anti-termination protein nusG } \\
\text { (NUSG) }\end{array}$ & 006795 & 31924 / 5.63 & 9 & $\begin{array}{l}\text { VIDGPFANFTGSIEEIDYDK VFVNMFGR ETPVE- } \\
\text { LEFTOIDK ANLEKR }\end{array}$ \\
\hline 24 & $\begin{array}{l}\text { Ferrichrome transport ATP-binding protein } \\
\text { (FHUC) }\end{array}$ & P49938 & 33229 / 5.67 & 10 & $\begin{array}{l}\text { ITTLIGPNGCGK STILKTMSRIMR WA- } \\
\text { LEETGMAEYAERPIEALSGGQR EG- } \\
\text { TALEVMTPDILK }\end{array}$ \\
\hline 25 & $\begin{array}{l}\text { Protein export protein prsA precursor } \\
\quad \text { (PRSA) }\end{array}$ & P24327 & $30331 / 5.85$ & 8 & $\begin{array}{l}\text { EVIAKTDAGDVTK GELYTNMK EQVKYELLTOKAAK } \\
\text { EYSTDSSASK }\end{array}$ \\
\hline 26 & Unknown protein & - & 32802 / 6.16 & - & \\
\hline 27 & Amidotransferase hisH (HIS5) & 034565 & $35465 / 5.84$ & 11 & $\begin{array}{l}\text { GKAVRLKAEDEKGNKLK LSFHNESPLLTK TEQ- } \\
\text { GYAYFVHSYYIDGMEENALLASADYGVR } \\
\text { SSTVGMSILTOFTKMAAEOKVK }\end{array}$ \\
\hline 28 & $\begin{array}{l}\text { Hypothetical } 35.0-\mathrm{kDa} \text { protein in rapJ-opuAA } \\
\text { intergenic region (YCEB) }\end{array}$ & 034504 & 43485 / 5.75 & 9 & $\begin{array}{l}\text { RYWFAEHHSTK GLASTAPEIMIAR IAAQTNTIR } \\
\text { QLEALYPNR }\end{array}$ \\
\hline 29 & $\begin{array}{l}\text { Hypothetical transcriptional regulator ybbB in } \\
\text { feuA-sigW intergenic region (ORF3) (YBBB) }\end{array}$ & P40408 & $57121 / 4.55$ & 18 & $\begin{array}{l}\text { MQNAVIYQPVQIEYLK ETGQDIFTPCTESELAK } \\
\text { LMNVSHIENLAVR LOELAALWNESSOLSOLK }\end{array}$ \\
\hline 30 & Unknown protein & - & $58250 / 6.07$ & - & \\
\hline 31 & $\begin{array}{l}\text { Glycine betaine/carnitine/choline transport } \\
\text { ATP-binding protein opuCA (OPCA) }\end{array}$ & 034992 & $54178 / 5.85$ & 12 & $\begin{array}{l}\text { CVIEVQSLIYDLFTASLSDOTDTHSAIEK WTSYYYQ- } \\
\text { HYSTDIPVQLSAYR LOELAALWNESSOLSQLK } \\
\text { MONAVIYOPVOIEYLK }\end{array}$ \\
\hline 32 & $\begin{array}{l}\text { Penicillin-binding protein 1A/1B (PBP1) } \\
\text { [Includes: penicillin-insensitive trans- } \\
\text { glycosylase (Peptidoglycan Tgase, PBPA) }\end{array}$ & P39793 & $49081 / 6.01$ & 10 & $\begin{array}{l}\text { AOPGSTIKPILDYGPVIENK OSVDGGSYSEIONSSAK } \\
\text { WLADYDOOTTAAK TGTGQLAQVPGVEVAGK }\end{array}$ \\
\hline 33 & PBSX phage terminase small subunit (XTMA) & P39785 & 43484 / 6.14 & 14 & $\begin{array}{l}\text { LSLYFDLFPDQFK DSGLVDGTIVTEAK TIGIWK } \\
\text { SFNATQSAIK }\end{array}$ \\
\hline 34 & $\begin{array}{l}\text { Probable amino-acid ABC transporter } \\
\text { ATP-binding protein in bmrU-ansR } \\
\text { intergenic region (YOIZ) }\end{array}$ & P54537 & $29604 / 6.05$ & 15 & $\begin{array}{l}\text { ENIGMVFOHFHLFPHK CLNLLEKPNGGTITIK } \\
\text { DTEITKPK EVLOVMK }\end{array}$ \\
\hline 35 & $\begin{array}{l}\text { Hypothetical 19.1-kDa protein in sigD-rpsB } \\
\text { intergenic region precursor (ORFC) (YLXL) }\end{array}$ & P40405 & $32236 / 6.30$ & 10 & $\begin{array}{l}\text { MSTLLWLLSFMLHGVLLYAVIILYTR OILEETEN- } \\
\text { TLAAFLLELK ASSASOSDEESOK TEIELFLK }\end{array}$ \\
\hline 36 & RIBT protein (RIBT) & P17622 & 18139 / 4.60 & 12 & EDEDIVGAIGVEK DYETDTDR HOGIGK OMMDALK \\
\hline 37 & PAL-related lipoprotein precursor (SLP) & P39910 & $18200 / 4.77$ & 13 & $\begin{array}{l}\text { AVFPMLIIVFALSGCTLSTI EGWE- } \\
\text { DEIETVPTLMVVDQR EDIIKPLOHVLSK DYPE- } \\
\text { OIDK }\end{array}$ \\
\hline 38 & Hypothetical protein YVYF (YVYF) & 2897794 & $17648 / 5.15$ & 14 & \\
\hline 39 & Unknown protein & P21468 & $12806 / 5.44$ & 10 & $\begin{array}{l}\text { DGFYOIVNVQSDAAAVOEFDR } \\
\text { FNNVLTSNGAEITGTK LAYEINDFR ISDDIIR }\end{array}$ \\
\hline 40 & $\begin{array}{l}\text { Phosphoadenosine phosphosulfate } \\
\text { reductase (PAPS reductase, Thioredoxin } \\
\text { dependent) (PADOPS reductase) } \\
\text { (3'-Phosphoadenylsulfate reductase) } \\
\text { (PAPS sulfotransferase) (CYH1) }\end{array}$ & P94498 & $22031 / 5.95$ & 9 & $\begin{array}{l}\text { MLTYDNWEEPTITFPEDDPYK KPDLTLEE- } \\
\text { OAEEHGDK DAEIVFLDTGLHFK EALSGH- } \\
\text { PAWLSGLR }\end{array}$ \\
\hline 41 & Unknown protein & - & $20546 / 6.05$ & - & \\
\hline 42 & $\begin{array}{l}\text { Hypothetical 73.2-kDa protein in sodA-comGA } \\
\text { intergenic region (YOGS) }\end{array}$ & P54496 & 38549 / 6.14 & 11 & $\begin{array}{l}\text { GAVFFTNAGNOYMAAPEILK ALADSNSLTEIE- } \\
\text { NYVTANAK DGSFITDOVVYTDGACYDK NVILVS- } \\
\text { LESTOSFVINEK }\end{array}$ \\
\hline
\end{tabular}


Table 1. Continued

\begin{tabular}{|c|c|c|c|c|c|}
\hline $\begin{array}{l}\text { Spot } \\
\text { no. }\end{array}$ & Protein name & $\begin{array}{l}\text { Acces- } \\
\text { sion no. }\end{array}$ & $\begin{array}{l}\text { Mol. mass } \\
(\mathrm{Da}) / \mathrm{p} /\end{array}$ & $\begin{array}{l}\text { No. peptide } \\
\text { matched }\end{array}$ & 4 sample matched peptides \\
\hline 43 & $\begin{array}{l}\text { Aspartokinase } 2 \text { (Aspartokinase II) } \\
\text { (Aspartate kinase 2) [contains: } \\
\text { aspartokinase II alpha subunit; } \\
\text { Aapartokinase II beta subunit] (AK2) }\end{array}$ & P08495 & 40764 / 6.32 & 13 & $\begin{array}{l}\text { ITDIDTSVLADOLEK GGSDTTAVALAAALK } \\
\text { GHOVVVVVSAMGK GIAFEDOITR }\end{array}$ \\
\hline 44 & $\begin{array}{l}\text { Hypothetical 45.3-kDa protein in prkA-cspB } \\
\text { intergenic region (ORF4) (YHBH) }\end{array}$ & P45742 & $43986 / 5.25$ & 17 & $\begin{array}{l}\text { HVGQGDGESOVGDVVAR TWNDITKPESK GE- } \\
\text { SGGTICSSVYR ELELPNLOOK }\end{array}$ \\
\hline 45 & Unknown protein & 007636 & $56284 / 5.35$ & 9 & $\begin{array}{l}\text { GNVTYPITIDPSVWIFDDR NAEPNS- } \\
\text { SATOCVFVTSSGK NEESGVSHQFS LMNGSFAMR }\end{array}$ \\
\hline 46 & $\begin{array}{l}\text { Hypothetical } 17.9-k D a \text { protein in nprE-pycA } \\
\text { intergenic region (YLAL) }\end{array}$ & - & $18200 / 4.77$ & - & \\
\hline 47 & Stage III sporulation protein $\mathrm{AH}$ & P49785 & $17587 / 5.64$ & 9 & $\begin{array}{l}\text { TVVTETADDDLFTTYR TQGYEDALVNAEGDK EEL- } \\
\text { NAIVSSDDATAK MTALSEVEGTGK }\end{array}$ \\
\hline 48 & (D49467) Unnamed protein product & P39807 & $56667 / 5.20$ & 9 & $\begin{array}{l}\text { DQMDHLNHEDALK DTYYAYNTK LOTVCQACIK } \\
\text { MGELANCPK }\end{array}$ \\
\hline 49 & $\begin{array}{l}\text { Prespore specific transcriptional activator } \\
\text { (RSFA) }\end{array}$ & P39650 & $58758 / 5.34$ & 11 & $\begin{array}{l}\text { ODAWSEENDLLLAETVLR FLONYEGNHEOSSALK } \\
\text { LVLFEEDEHASPSFK TIOEDYETLVK }\end{array}$ \\
\hline 50 & $\begin{array}{l}\text { Glucose-6-phosphate isomerase (GPI) } \\
\text { (Phosphoglucose isomerase) (PGI) } \\
\text { (Phosphohexose isomerase) (PHI) (G6PI) }\end{array}$ & P80860 & $58515 / 5.52$ & 21 & $\begin{array}{l}\text { TGAGSDFLGWVDLPEHYDK DVMDLLEDVDFSIN- } \\
\text { VISK GNPOVIFIGNNISSSYMR ALTFFPTE- } \\
\text { HELTYLR }\end{array}$ \\
\hline 51 & Unknown protein & - & 20249 / 5.07 & - & \\
\hline 52 & $\begin{array}{l}\text { Hypothetical 21.0-kDa protein in lysS-mecB } \\
\text { intergenic region (YACH) }\end{array}$ & P37569 & $17461 / 5.70$ & 10 & $\begin{array}{l}\text { ELESLIHOEEFENAAHVR MICQECHERPATFHFTK } \\
\text { VNMFALLGKPGFEEK STDSEEEOEVNK }\end{array}$ \\
\hline 53 & $\begin{array}{l}\text { Molybdopterin-gianine dinucleotide } \\
\text { biosynthesis protein B }\end{array}$ & 031704 & $18445 / 5.87$ & 9 & $\begin{array}{l}\text { LIELYOFLETDCLLIEGFK MAL- } \\
\text { VRPFPIVOVVGFONSGK EDLEALOAVNIIAIIYR } \\
\text { AAGADVTAVEGAGVLOLTAR }\end{array}$ \\
\hline
\end{tabular}

tein, while the cold-shock-induced proteins at $25^{\circ} \mathrm{C}$ were glucosyltransferase, anti- $\sigma \mathrm{B}$ factor, and hypothetical transcriptional regulator in FeuA-SigW intergenic region, phosphoadenosine phosphosulfate reductase and prespore specific transcriptional activator. This result suggested that the temperatures of cold-shock experiment highly influenced the levels of the protein synthesis.

\subsection{Cold-shock effect on sporulation signaling pathway of $B$. stearothermophilus TLS33}

To gain a better understanding of the bacterial adaptation under cold-shock stress, advanced bioinformatics based on database searches was used to thoroughly search the specific cold-shock-induced proteins and the relationship between their functions and signal transduction pathways of bacterial adaptation when the bacterium was subjected cold-shock stress. Only six proteins, TagE, RsbT, MrpA, PyrC, YbbB and RsfA, were shown to have the functions correlated to the signaling pathway of sporulation. Regarding sporulation in $B$. subtilis, it has been reported that these proteins were also correlated with the $\sigma \mathrm{F}$ and $\sigma \mathrm{G}$ factors, which are involved in the 'Forespore' stage of the sporulation process [40]. We pro- pose that the functions of the cold-shock-induced proteins in the sporulation signaling pathway corelates to five routes. In the first route, RsbT is up-regulated when the bacterium is cold-shocked at only $25^{\circ} \mathrm{C}$. Generally, RsbT controls the early sporulation in vegetative cell cycle of Bacillus sp. by coordination with the $\sigma^{\mathrm{B}}$ factor [41-45]. When the bacterium is exposed to stress, RsbT from the upstream module is triggered to inactivate the principal negative regulator of RsbS by phosphorylation, and then to activate RsbU. Subsequently, PP2C phosphatase can dephosphorylate the phosphorylated form of RsbV (RsbV-P) to its dephosphorylated form (RsbV) in the downstream module (Fig. 5A). RsbV forms a complex with RsbW and forces the release of $\sigma^{\mathrm{B}}$. Thus, RsbT is linked to the upstream and downstream modules, which activates RsbU and stimulates its enzymatic properties towards its substrate [46-53]. In the second route, TagE has two activities in stressed cells, in which it activates the PAS-RsbP to form a complex with RsbW, and alternately activates the $\sigma^{\mathrm{F}} / \sigma^{\mathrm{G}}$ in the forespore via RsbW/ $\sigma^{\mathrm{B}}$ route (Fig. $5 \mathrm{~B}$ ). Only this route is activated when the bacterium is cold-shocked at $37^{\circ} \mathrm{C}$ or $25^{\circ} \mathrm{C}$. We suggest that this route may be dormant at $65^{\circ} \mathrm{C}$ because the protein has not been observed. It has been reported that TagE is involved in the activation of $\mathrm{PhoP} \sim \mathrm{P}$ 
Table 2. Protein and gene identification, description, and functional category of intracellular proteins in $B$. stearothermophilus TLS33, after downshift temperatures at $37^{\circ} \mathrm{C}$ and $25^{\circ} \mathrm{C}$, by SubtiList and EMBL/GenBank/DDBJ databanks and COG databases

\begin{tabular}{|c|c|c|c|c|}
\hline $\begin{array}{l}\text { Spot } \\
\text { no. }\end{array}$ & Protein ID/no. & Gene name/no. & Description & Functional category \\
\hline 1 & PTFB (P26380) & levE (X56098) & $\begin{array}{l}\text { PTS fructose-specific enzyme } \\
\text { IIB component }\end{array}$ & $\begin{array}{l}\text { Transport/binding proteins and } \\
\text { lipoproteins }\end{array}$ \\
\hline 2 & S3AE (P49782) & spollIAE (U35252) & $\begin{array}{l}\text { Mutants block sporulation after } \\
\text { engulfment }\end{array}$ & Sporulation \\
\hline 3 & IMDH (P21879) & guaB (X55669) & $\begin{array}{l}\text { Inosine-monophosphate } \\
\text { dehydrogenase }\end{array}$ & $\begin{array}{l}\text { Metabolism and transport of nucleotides } \\
\text { and nucleic acids (purine biosynthesis) }\end{array}$ \\
\hline 4 & CMF3 (P39147) & comFC (Z18629) & Late competence gene & Transformation /competence \\
\hline 5 & Unknown & - & - & - \\
\hline 6 & FLIT (P39740) & fliT (Z31376) & Flagellar protein & Mobility and chemotaxis \\
\hline 7 & TOP1 (P39814) & topA (L27797) & DNA topoisomerase I & $\begin{array}{l}\text { DNA packing and segregation / DNA } \\
\text { replication, recombination }\end{array}$ \\
\hline 8 & TAGE (P13484) & $\operatorname{tag} \mathrm{E}(\mathrm{X} 15200)$ & $\begin{array}{l}\text { UDP-glucose: polyglycerol phosphate } \\
\text { glucosyltransferase }\end{array}$ & Cell wall \\
\hline 9 & IF2 (P17889) & infB (M34836) & Initiation factor IF-2 (GTPase) & $\begin{array}{l}\text { Initiation, translation factors and } \\
\text { enzymes involved in translation }\end{array}$ \\
\hline 10 & YQHT (P54518) & yqhT (D84432) & $\begin{array}{l}\text { Unknown; similar to Xaa-Pro } \\
\text { dipeptidase }\end{array}$ & Protein modification \\
\hline 11 & RSBT (P42411) & rsbT (L35574) & $\begin{array}{l}\text { Positive regulator of sigma-B } \\
\text { activity (switch protein/serine- } \\
\text { threonine kinase) }\end{array}$ & Adaptation to atypical conditions \\
\hline 12 & SUHB (045499) & $\operatorname{suhB}(\mathrm{AF} 012285)$ & $\begin{array}{l}\text { Archaeal fructose-1,6-biphosphate } \\
\text { and related enzyme of inositol } \\
\text { monophosphatase family }\end{array}$ & Carbohydrate transport and metabolism \\
\hline 13 & Unknown & - & - & - \\
\hline 14 & YPBG (P50733) & ypbG (L47648) & $\begin{array}{l}\text { Unknown; similar to unknown } \\
\text { proteins }\end{array}$ & From other organisms \\
\hline 15 & Unknown & - & - & - \\
\hline 16 & LEPA (P37949) & lepA (X91655) & GTP-binding protein & Elongation \\
\hline 17 & PMGI (P39773) & pgm (L29475) & Phosphoglycerate mutase & $\begin{array}{l}\text { Carbohydrate transport and metabolism } \\
\text { (gluconeo-genesis) }\end{array}$ \\
\hline 18 & Unknown & - & - & - \\
\hline 19 & MSRA (P54154) & msrA (L77246) & $\begin{array}{l}\text { Peptidyl methione sulfoxide } \\
\text { reductase }\end{array}$ & $\begin{array}{l}\text { Detoxification, post-translational modi- } \\
\text { fication, protein turnover, chaperone }\end{array}$ \\
\hline 20 & MRP (P50863) & $m r p(X 74737)$ & $\begin{array}{l}\text { Multiple resistance and } \mathrm{pH} \\
\text { homeostasis }\end{array}$ & Transport/binding proteins \\
\hline 21 & YPWA (P50848) & ypwA (L47838) & $\begin{array}{l}\text { Unknown; similar to } \\
\text { carboxypeptidase }\end{array}$ & $\begin{array}{l}\text { Metabolism of amino acids and related } \\
\text { molecule }\end{array}$ \\
\hline 22 & PYRC (P25995) & pyrC (BG10714) & $\begin{array}{l}\text { Dihydroorthase (Pyrimidine } \\
\text { biosynthesis) }\end{array}$ & $\begin{array}{l}\text { Metabolism of nucleotides and nucleic } \\
\text { acids }\end{array}$ \\
\hline 23 & NUSG (Q06795) & nusG (D13303) & Transcription anti-termination factor & Termination \\
\hline 24 & FHUC (P49938) & fhuC (X93092) & $\begin{array}{l}\text { Ferrichrome } A B C \text { transporter } \\
\text { (ATP-binding protein) }\end{array}$ & $\begin{array}{l}\text { Transport/binding proteins and lipopro- } \\
\text { teins }\end{array}$ \\
\hline 25 & PRSA (P24327) & prsA (X57271) & $\begin{array}{l}\text { Protein secretion (post-translocation } \\
\text { molecular chaperone), } \\
\text { phosphoribosylpyrophosphate } \\
\text { synthetase }\end{array}$ & $\begin{array}{l}\text { Protein secretion, nucleotide and amino } \\
\text { acid transport and metabolism }\end{array}$ \\
\hline 26 & Unknown & - & - & - \\
\hline
\end{tabular}


Table 2. Continued

\begin{tabular}{|c|c|c|c|c|}
\hline $\begin{array}{l}\text { Spot } \\
\text { no. }\end{array}$ & Protein ID/no. & Gene name/no. & Description & Functional category \\
\hline 27 & HIS5 (034565) & hisH (AF017113) & Amidotransferase & $\begin{array}{l}\text { Amino acid transport and metabolism } \\
\text { (histidine bio-synthesis) }\end{array}$ \\
\hline 28 & YCEB (034504) & yceB (AB000617) & Unknown; similar to unknown proteins & From other organisms \\
\hline 29 & YBBB (P40408) & ybbB (L19954) & $\begin{array}{l}\text { Unknown; similar to transcriptional } \\
\text { regulator (AraC/XylS family) }\end{array}$ & Regulation \\
\hline 30 & Unknown & - & - & - \\
\hline 31 & OPCA (O34992) & opuCA (AF009352) & $\begin{array}{l}\text { Glycine betaine/carnitine/ choline ABC } \\
\text { trans-porter (ATP-binding protein) }\end{array}$ & $\begin{array}{l}\text { Transport/binding proteins and } \\
\text { lipoproteins }\end{array}$ \\
\hline 32 & PBPA (P39793) & ponA (U11883) & Penicillin-binding proteins 1A/1B & Cell wall \\
\hline 33 & XTMA (P39793) & $x \operatorname{tmA}(Z 70177)$ & Phage PBSX terminase (small subunit) & $\begin{array}{l}\text { Phage-related functions, DNA replica- } \\
\text { tion, recombination and repair }\end{array}$ \\
\hline 34 & YOIZ (P54537) & yqIZ (D84432) & $\begin{array}{l}\text { Unknown; similar to amino acid ABC } \\
\text { transporter (ATP-binding protein) }\end{array}$ & $\begin{array}{l}\text { Transport/binding proteins and } \\
\text { lipoproteins }\end{array}$ \\
\hline 35 & YLXL (P40405) & $y / x L(Z 99112)$ & Unknown; similar to unknown proteins & From B. subtilis \\
\hline 36 & RIBT (P17622) & ribT (L09228) & Reductase & $\begin{array}{l}\text { Metabolism of coenzymes and pro- } \\
\text { sthetic groups, riboflavin biosynthesis }\end{array}$ \\
\hline 37 & SLP (P39910) & slp (M57435) & $\begin{array}{l}\text { Small peptidoglycan-associated } \\
\text { lipoprotein, starvation-inducible } \\
\text { outer membrane lipoprotein }\end{array}$ & $\begin{array}{l}\text { Transport/binding proteins and } \\
\text { lipoproteins, cell envelope } \\
\text { biogenesis, outer membrane }\end{array}$ \\
\hline 38 & YVYF (P39807) & $y v y F(\mathrm{~L} 14437)$ & Unknown; similar to flagellar protein & Mobility and chemotaxis \\
\hline 39 & Unknown & - & - & - \\
\hline 40 & CYH1 (P94498) & cysH (U76751) & Phosphoadenosine phosphosulfate & $\begin{array}{l}\text { Amino acid transport and metabolism, } \\
\text { coenzyme metabolism } \\
\text { (FAD biosynthesis) }\end{array}$ \\
\hline 41 & Unknown & - & - & - \\
\hline 42 & YQGS (P54496) & yqgS (D84432) & $\begin{array}{l}\text { Unknown; similar to putative } \\
\text { molybdate binding protein }\end{array}$ & From other organisms \\
\hline 43 & AK2 (P08495) & lysC (J03294) & $\begin{array}{l}\text { Aspartokinase II (alpha and beta } \\
\text { subunits) }\end{array}$ & $\begin{array}{l}\text { Amino acid transport and metabolism } \\
\text { (threonine and methionine } \\
\text { biosynthesis) }\end{array}$ \\
\hline 44 & YHBH (P45742) & yhbH (Z99108) & $\begin{array}{l}\text { Ribosome-associated protein } Y \\
\quad \text { (PSrp-1) }\end{array}$ & $\begin{array}{l}\text { Translation, ribosomal structure and } \\
\text { biogenesis }\end{array}$ \\
\hline 45 & Unknown & - & - & - \\
\hline 46 & YLAL (007636) & ylaL (Z99111) & - & - \\
\hline 47 & $\mathrm{AH}(\mathrm{P} 49785)$ & spollIAH (Z99116) & - & - \\
\hline 48 & $\begin{array}{l}\text { Unnamed protein } \\
\text { (BAA24873) }\end{array}$ & - & Unknown; similar to flagellar proteins & Mobility and chemotaxis \\
\hline 49 & RSFA (P39650) & rsfA (X73124) & $\begin{array}{l}\text { Probable regulator of transcription of } \\
\text { sigma-F-dependent genes, leucine } \\
\text { zipper motif }\end{array}$ & Sporulation \\
\hline 50 & G6PI (P80860) & pgi (Z93936) & Glucose-6-phosphate isomerase & $\begin{array}{l}\text { Carbohydrate transport and metabolism } \\
\text { (glycolysis, gluconeogenesis) }\end{array}$ \\
\hline 51 & YOBP (P45932) & $y q b \mathrm{P}(\mathrm{D} 32216)$ & $\begin{array}{l}\text { Unknown; similar to phage-related } \\
\text { protein }\end{array}$ & Phage-related functions \\
\hline 52 & YACH (P37569) & yacH (D26185) & Unknown & - \\
\hline 53 & MOBB (O31704) & mobB (AF012285) & $\begin{array}{l}\text { Molybdopterin-guanine dinucleotide } \\
\text { biosynthesis }\end{array}$ & $\begin{array}{l}\text { Metabolism of coenzymes and pro- } \\
\text { sthetic groups }\end{array}$ \\
\hline
\end{tabular}


Table 3. Comparison of the functional systems of the Bacillus sp. in protein-coding genes using the COG and SubtiList databases. The pathway and functional systems are classified from COG database using COGNITOR program

\begin{tabular}{|c|c|c|c|}
\hline Functional systems & B. subtilis & B. halodurans & B. stearothermophilus TLS33 ${ }^{\mathrm{a})}$ \\
\hline \multicolumn{4}{|l|}{ Information storage and processing } \\
\hline $\begin{array}{l}\text { 1. Translation, ribosomal structure } \\
\text { and biogenesis }\end{array}$ & 152 & 153 & $3(i n f \mathrm{~B}, y h b \mathrm{H}, y b b \mathrm{~B})$ \\
\hline 2. Transcription & 272 & 269 & 2 (nusG, rsfA) \\
\hline 3. DNA replication, recombination and repair & 131 & 227 & 2 (topA, $x \operatorname{tmA})$ \\
\hline \multicolumn{4}{|l|}{ Cellular processes } \\
\hline 1. Cell division and chromosome partitioning & 31 & 32 & 1 (mrp) \\
\hline $\begin{array}{l}\text { 2. Posttranslational modification, } \\
\text { protein turnover, chaperones }\end{array}$ & 87 & 84 & $2(m s r A, y q h T)$ \\
\hline 3. Cell envelope biogenesis, outer membrane & 161 & 115 & $\begin{array}{l}6 \text { (slp, spollIAE, ponA, tagE, } \\
\quad y q \mathrm{Z}, \text { rsfA) }\end{array}$ \\
\hline 4. Cell motility and secretion & 90 & 90 & $3($ lepA, fliT, yvyF) \\
\hline 5. Inorganic ion transport and metabolism & 148 & 146 & 2 (fhuC, opuCA) \\
\hline 6. Signal transduction mechanisms & 122 & 135 & - \\
\hline \multicolumn{4}{|l|}{ Metabolism } \\
\hline 1. Energy production and conversion & 164 & 158 & - \\
\hline 2. Carbohydrate transport and metabolism & 271 & 262 & 3 (suhB, pgm, pgi) \\
\hline 3. Amino acid transport and metabolism & 293 & 284 & $\begin{array}{l}6 \text { (prsA, his } \mathrm{H}, c y s \mathrm{H}, \text { lys } \mathrm{C}, \text { levE, } \\
\quad \text { ypwA) }\end{array}$ \\
\hline 4. Nucleotide transport and metabolism & 82 & 73 & $2(p r s \mathrm{~A}, g u a \mathrm{~B})$ \\
\hline 5. Coenzyme metabolism & 109 & 109 & 5 (fhuC, cysH, mobB, opuCA) \\
\hline 6. Lipid metabolism & 84 & 89 & - \\
\hline $\begin{array}{l}\text { 7. Secondary metabolites biosynthesis, } \\
\text { transport and catabolism }\end{array}$ & 128 & 110 & - \\
\hline \multicolumn{4}{|l|}{ Poorly characterized } \\
\hline 1. General function prediction only & 332 & 329 & $3(c o m F C, y b b \mathrm{~B}, r s b \mathrm{~T})$ \\
\hline 2. Function unknown & 226 & 246 & $\begin{array}{l}5 \text { (ypbG, yceB, yqgS, yhbH, } \\
\quad \text { ylaL) }\end{array}$ \\
\hline Not in COGs & 1221 & 1155 & - \\
\hline
\end{tabular}

a) Some identification

under conditions of phosphate starvation since the coldstress regulon was under the control of the alternative signaling pathway of $\sigma^{\mathrm{B}}[54-56]$. In the third route, YbbB activates FeuA to form a complex with RsbW, leading to release the $\sigma^{\mathrm{B}}$ from RsbW- $\sigma^{\mathrm{B}}$ complex and subsequently convert to $\sigma^{\mathrm{F}}$ or $\sigma^{\mathrm{G}}$ in the forespore (Fig. $5 \mathrm{C}$ ). In the fourth route, RsfA is also activated when the bacterium is cold-shocked at $37^{\circ} \mathrm{C}$ or $25^{\circ} \mathrm{C}$. RsfA can directly activate $\sigma^{\mathrm{F}} / \sigma^{\mathrm{G}}$ in the forespore (Fig. 5D). The activation of $\sigma^{\mathrm{F}}$ in the forespore could lead to transcription of SpoIIR and SpoIIQ, and disrupt, without preventing, the formation of stress-resistant spores. $\sigma^{\mathrm{G}}$ could then activate transcription in the engulfed forespore of a large set of genes $[40,57]$. In the fifth route, MrpA and PyrC proteins are correlated in the signaling pathway of bacterial sporulation, in which they are down-regulated when the bacterium is cold-shocked at $37^{\circ} \mathrm{C}$ or $25^{\circ} \mathrm{C}$ (Fig. 5E). Both of MrpA and PyrC indirectly activate a transcription factor $\sigma^{\mathrm{H}}$, leading to $\sigma^{\mathrm{F}} / \sigma^{\mathrm{G}}$ production in the forespore stage. The MRP protein homolog is the multi-resistance protein and functions as an $\mathrm{Na}^{+} / \mathrm{H}^{+}$antiporter in $\mathrm{pH}$ homeostasis, by which it could influence to the post-translational regulation control of $\sigma^{\mathrm{H}}$ in the early sporulation in cell cycle $[58,59]$. On the other hand, PyrC or dihydroorthase could function in the regulation of pyrimidine biosynthesis and the control of gene expression [60]. According to the correlation of the coldshock-induced proteins in signaling pathway of sporulation, 


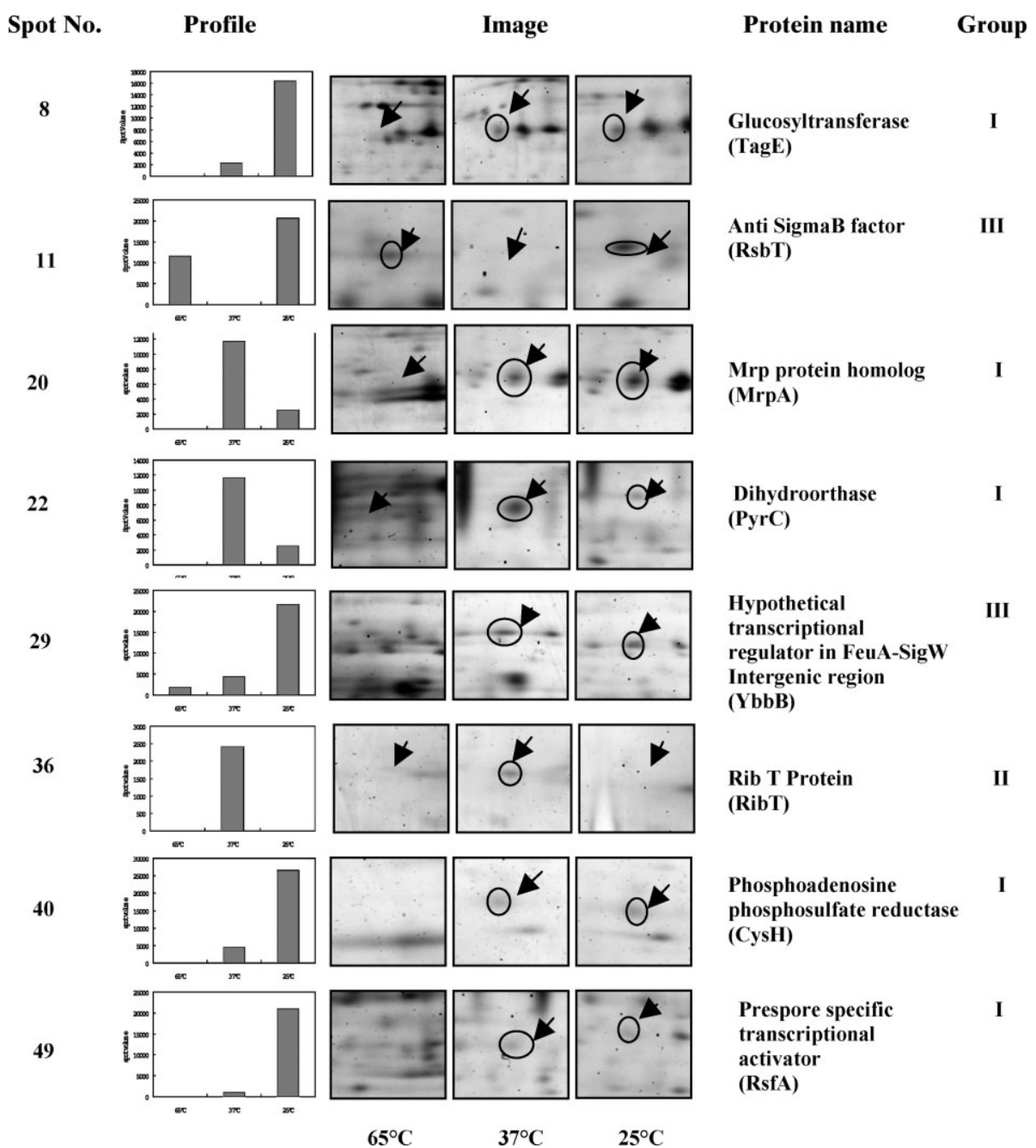

Figure 4. Image analysis of eight major cold-shock-induced proteins of $B$. stearothermophilus TLS33 under coldshock stress using ImageMaster 2D Elite software. The arrows on 2-D gels show the situation of protein spots. Three groups of cold-shock-induced proteins are classified by ImageMaster 2D Elite software. (I, protein synthesis at $37^{\circ} \mathrm{C}$ and $25^{\circ} \mathrm{C}$; II, protein synthesis at $37^{\circ} \mathrm{C}$; III, protein synthesis at $65^{\circ} \mathrm{C}$ and $25^{\circ} \mathrm{C}$. we presume that up- and down-regulation of these proteins are involved in the $\sigma^{\mathrm{F}} / \sigma^{\mathrm{G}}$ production in the forespore (Fig. 6). Thus, the forespore is also considered as an event proceeding bacterial sporulation in the environmental cold-shock stress.

These observations demonstrate the correlation of six major cold-shock-induced proteins when the bacterium encounters cold-shock stress (Fig. 7). TagE, YbbB, RsfA and $\mathrm{RsbT}$, the upstream proteins, are activated in the low temperature at $37^{\circ} \mathrm{C}$ or $25^{\circ} \mathrm{C}$, whereas MrpA and PyrC are inactivated, representing downstream proteins. Surprisingly, RsbT is observed at $65^{\circ} \mathrm{C}$ and $25^{\circ} \mathrm{C}$, but not at $37^{\circ} \mathrm{C}$. We suggest that normally, RsbT would be inactive at $65^{\circ} \mathrm{C}$, the optimal temperature for this bacterium, and associated with a negative regulator RsbU [49]. To explain the fact that RsbT is not observered by proteomic analysis at $37^{\circ} \mathrm{C}$, two hypotheses can be proposed, linking RsbT to upstream and downstream modules of the sporulation signaling pathway. First, the 2 -h cold-shock stress at $37^{\circ} \mathrm{C}$ may initiate the bacterial shock response in which RsbT can form a complex in the upstream module or be subjected to the translational regulation [46]. Second, the temperature at $37^{\circ} \mathrm{C}$ may not be low enough to induce this cold-shock-induced protein [61]. Although RibT and CysH can be observed at $37^{\circ} \mathrm{C}$ and $25^{\circ} \mathrm{C}$, they are not involved in the signaling pathway of sporulation. RibT protein generally functions as a reductase enzyme in riboflavin or vitamin $\mathrm{B}_{2}$ biosynthesis and reduction metabolism [62, 63]. However, the function of RibT, which preferentially appeared at only $37^{\circ} \mathrm{C}$, has not yet been clarified in Bacillus sp. and other bacterial species [64-69]. Likewise, CysH protein, observed at the low temperatures, has also been demonstrated to be involved in the regulation of the sulfur starvation [70]. Thus, RibT and CysH are not part of this signaling pathway. Although other related proteins involved in the TagE, YbbB, RsfA, MrpA and PyrC routes at $65^{\circ} \mathrm{C}$ can not be identified, this may be due to the limitation of the proteomic analysis in this study. This failure may be caused by post-translational modifications, such as glycosylation or phosphorylation, or by the regulation of gene expression; for example, tagE, $\gamma b b \mathrm{~B}$ and $r s f \mathrm{~A}$ genes are turned on at $37^{\circ} \mathrm{C}$, while $m r p \mathrm{~A}$ and $p y r C$ genes are turned off. If this proposal is valid, it is necessary to determine the unknown genes involved in the upstream module of the 

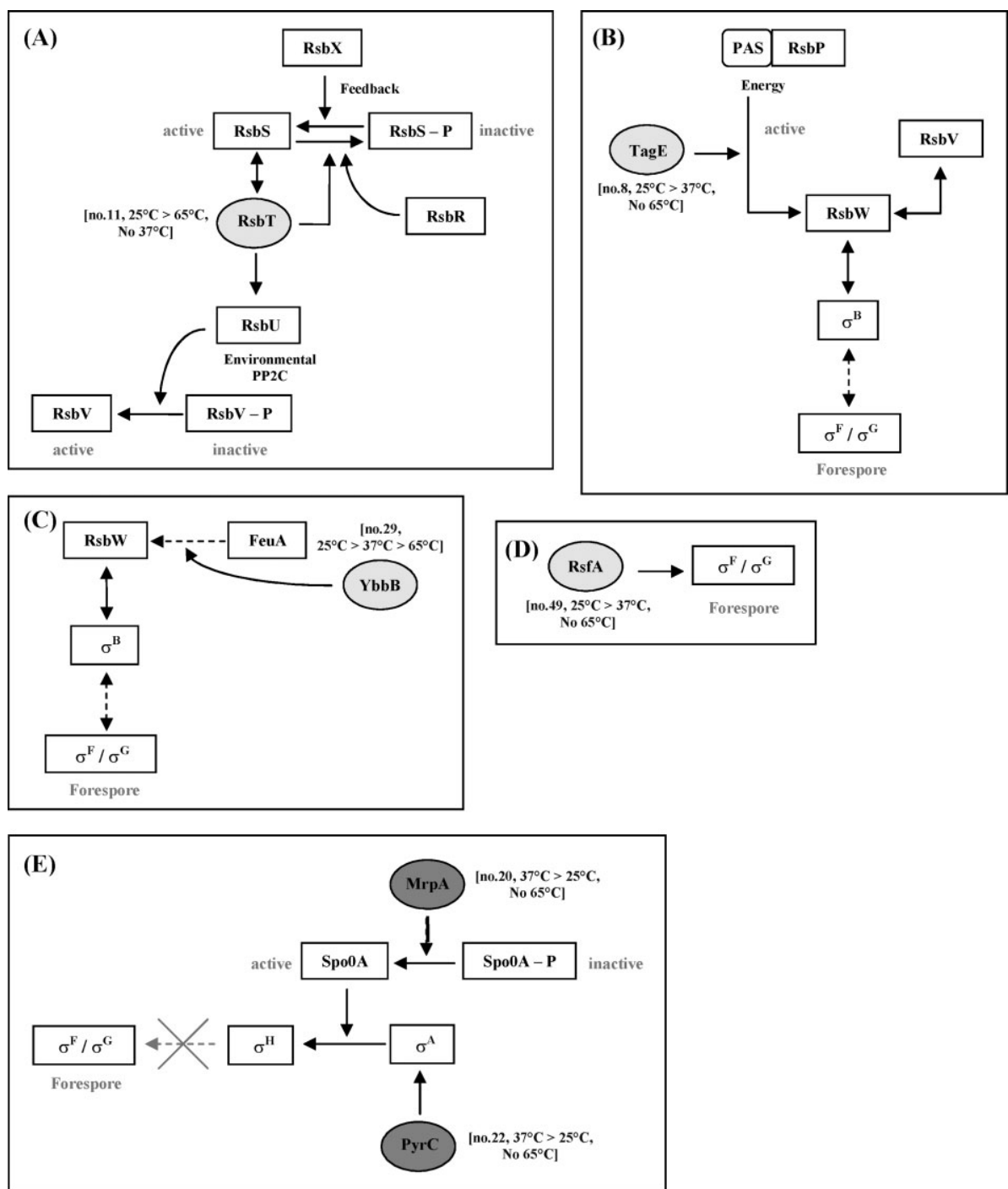

signaling pathway. The proteome of B. stearothermophilus TLS33 under cold-shock stress is being studied further to obtain a more complete understanding of the biological events.

\section{Concluding remarks}

In summary, this is the first report of the thermophilic bacterium B. stearothermophilus TLS33 proteome, which correlates the signaling pathway of bacterial sporulation, under cold-shock stress. Using a proteomic approach combining 2-DE and MALDI-TOF analysis, individual proteins were identified and shown to have biological functions in the metabolic system of bacterial cell adaptation. Interestingly, six cold-shock-induced proteins were shown to correlate with the sigma B protein, which plays an important role in the signal transduction pathway of sporulation in this bacteri-
Figure 5. Correlation of the cold-shock-induced proteins in signal transduction pathway of B. stearothermophilus TLS33 sporulation under cold-shock stress. (A) RsbT route; (B) TagE route; (C) YbbB route; (D) RsfA route; (E) MrpA and PyrC routes. um. Thus, this study adds to our understanding of bacterial adaptation under cold-shock stress. However, this thermophile needs to be studied further both with regard to its the biological functions and mechanisms, also at the gene expression level, under different stresses, as well as to the proteins that play an important role in the industrial and pharmaceutical applications.

This report is part of Royal Golden Jubilee Ph.D. project of Mr. Supachai Topanurak supported by the Thailand Research Fund (TRF), Thailand. We gratefully acknowledge the support of the National Research Program for Genomic Medicine of National Science Council, Taiwan (NSC 91-3112-13-001002) and the support of Academia Sinica, Taiwan for a grant of the Bacillus research. We thank the core facilities for proteomic research, Academia Sinica, Taiwan for proteomics facilities, and the Graduate School, Chiang Mai University, Thailand for 


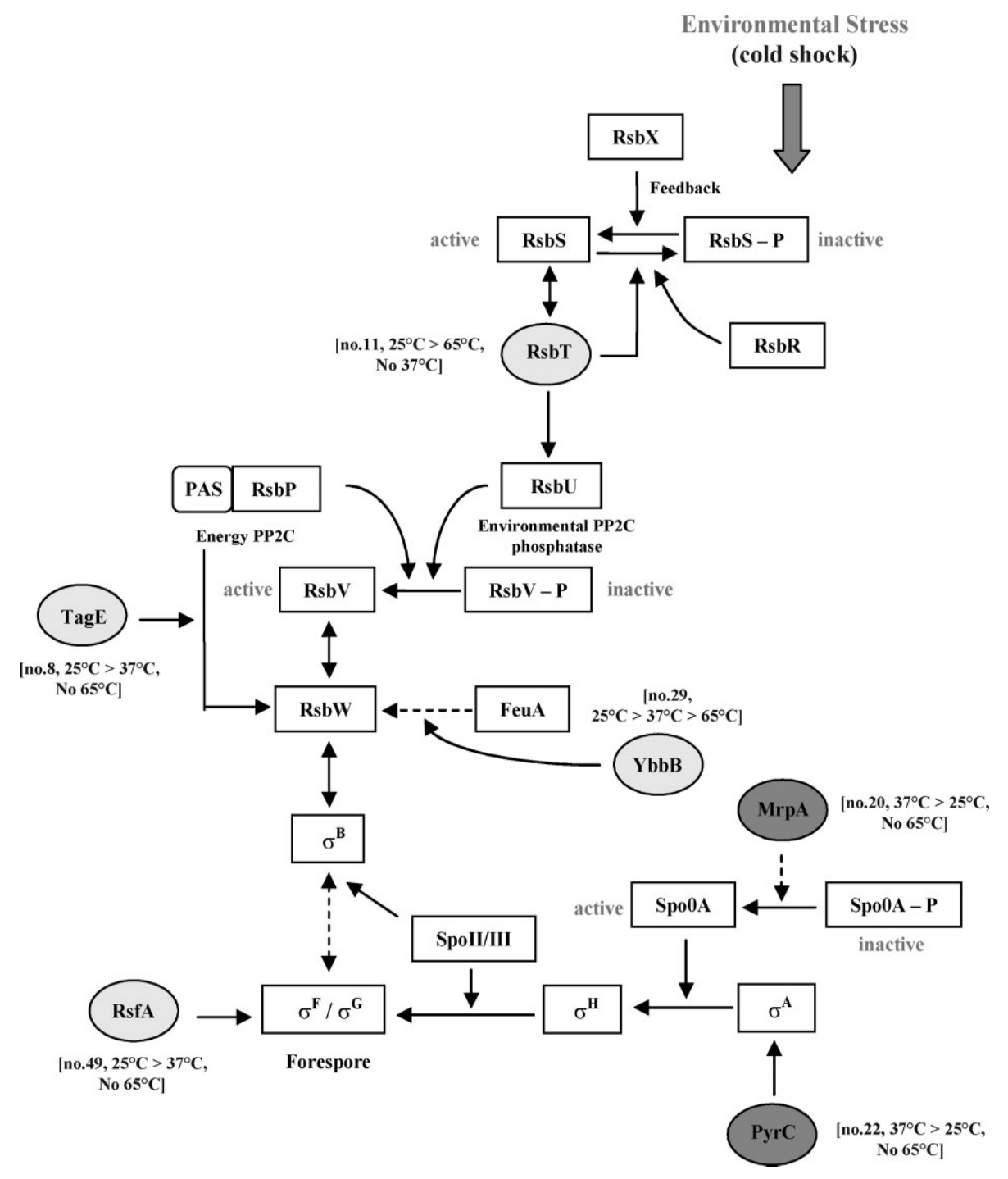

Figure 6. Model summarizing the signal transduction pathway of $B$. stearothermophilus TLS33 sporulation under cold-shock stress.

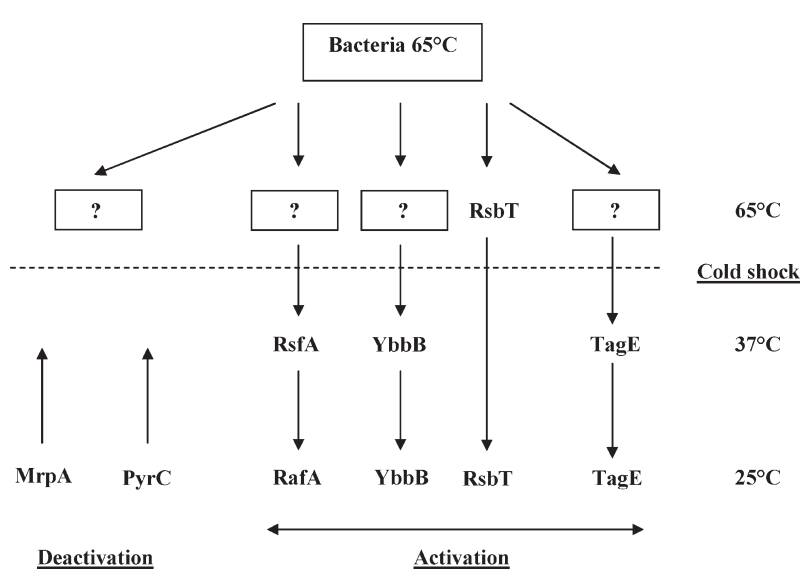

Figure 7. Up- and down-regulations of the six major cold-shockinduced proteins when B. stearothermophilus TLS33 encounters cold-shock stress. The direction of arrows represents the change of the protein expression. accomplishing this project. Finally, we also thank Albert Tseng and John Y. Lin for critical reading and revising of this manuscript.

\section{References}

[1] Thieringer, H. A., Jones, P. G., Inouye, M., BioEssays 1998, 20 , 49-57.

[2] Brock, T. D., Madigan, M. T., Biology and Microorganisms, 5th edn., Prentice Hall, Englewood Cliffs 1980, pp. 330-335.

[3] Morita, R. Y., Bacteriol. Rev. 1975, 29, 144-167.

[4] Graumann, P. L., Marahiel, M. A., Arch. Microbiol. 1996, 166, 293-300.

[5] Jones, P. G., VanBogelen, R. A., Neidhardt, F. C., J. Bacteriol. 1987, 169, 2092-2095.

[6] La Teana, A., Brandi, A., Falconi, M., Spurio, R., Pon, C. L., Gualerzi, C. O., Proc. Natl. Acad. Sci. USA 1991, 88, 1090710911. 
[7] Oing, G., Ma, L. C., Khorchid, A., Swapna, G. V., Mal, T. K., Takayama, M. M., Xia, B. et al., Nat. Biotechnol. 2004, 22, 877-882.

[8] Phadtare, S., Inouye, M., J. Bacteriol. 2004, 186, 7007-7014.

[9] Wick, L. M., Engli, T., Adv. Biochem. Eng. Biotechnol. 2004, 80, 1-45.

[10] Mihoub, F., Mistou, M. Y., Guillot, A., Leveau, J. Y., Boubetra, A., Billaux, F., Int. J. Food Microbiol. 2003, 89, 171-184.

[11] Yamanaka, K. J., Mol. Microbiol. Biotechnol. 1999, 1, 193202.

[12] Phadtare, S., Alsina, J., Inouye, M., Curr. Opin. Microbiol. $1999,2,175-180$

[13] Kaan, T., Homuth, G., Mader, U., Bandow, J., Schweder, T., Microbiol. 2002, 148, 3441-3455.

[14] Beckering, C. L., Steil, L., Weber, M. H., Volker, U., Marahiel, M. A., J. Bacteriol. 2002, 284, 6395-6402.

[15] Hecker, M., Adv. Biochem. Eng. Biotechnol. 2003, 83, 57-92.

[16] Petersohn, A., Brigulla, M., Haas, S., Hoheisel. J. D., Volker, V., Hecker, M., J. Bacteriol. 2001, 183, 5617-5631.

[17] Mueller, U., Perl, D., Schmid, F. X., Heinemann, U., J. Mol. Biol. 2000, 297, 975-988.

[18] Hasegawa, Y., Kawada, N., Nosoh, Y., Arch. Microbiol. 1980, 126, 103-108.

[19] Perl, D., Welker, C., Schindler, T., Schroder, K., Marahiel, M. A., Jaenicke, R., Schmid, F. X., Nat. Struct. Biol. 1998, 5, 229 235.

[20] Welker, C., Bohm, G., Schurig, H., Jaenicke, R., Protein Sci. 1999, 8, 394-403.

[21] Sinchaikul, S., Sookkheo, B., Pan, F. M., Phutrakul, S., Chen, S. T., Proteomics 2002, 2, 1316-1324.

[22] Sinchaikul, S., Sookkheo, B., Topanuruk, S., Juan, H. F., Phutrakul, S., Chen, S. T., J. Chromatogr. B 2002, 771, 261287.

[23] VanBogelen, R. A., Sanker, P., Clark, R. L., Bogan, J. A., Neidhardt, F. C., Electrophoresis 1992, 13, 1014-1054.

[24] Pasquali, C., Frutiger, S., Wilkins, M. R., Hughes, G. J., Appel, R. D., Bairoch, A., Schaller, D. et al., Electrophoresis 1996, 17, 547-555.

[25] Volker, U., Englemann, S., Maul, B., Reithdorf, S., Volker, A., Schmid, R., Mach, H., Hecker, M., Microbiology 1994, 140, 741-752.

[26] Büttner, K., Bernhardt, J., Scharf, C., Schmid, R., Mäder, U., Eymann, C., Antelmann, H. et al., Electrophoresis 2001, 22, 2908-2935.

[27] Shevchenko, A., Jensen, O. N., Podtelejnikov, A. V., Sagliocco, F., Wilm, M., Vorm, O., Mortensen, P. et al., Proc. Natl. Acad. Sci. USA 1996, 93, 14440-14445.

[28] Movahedi, S., Waites, W., J. Bacteriol. 2002, 184, 5275-5281.

[29] Rabilloud, T., Electrophoresis 1998, 19, 758-760.

[30] Berggren, K., Chernokalskaya, E., Steinberg, T. H., Kemper, C., Lopez, M. F., Diwu, Z., Haugland, R. P., Patton, W. F., Electrophoresis 2000, 21, 2509-2521.

[31] Dainese, P., Staudenmann, W., Ouadroni, M., Korostensky, C., Gonnet, G., Kertesz, M., James, P., Electrophoresis 1997, $18,432-442$.

[32] Msadek, T., Trends Microbiol. 1999, 7, 201-207.

[33] Kroos, L., Zhang, B., Ichikawa, H., Yu, Y. T. N., Mol. Microbiol. $1999,31,1285-1294$
[34] Weber, M. H. W., Marahiel, M. A., Sci. Prog. 2003, 86, 9-75.

[35] Graumann, P., Schroder, K., Schmid, R., Marahiel, M. A., J. Bacteriol. 1996, 178, 4611-4619.

[36] Graumann, P., Wendrich, T. M., Weber, M. H. W., Svhroder, K., Mirahiel, M. A., Mol. Microbiol. 1997, 25, 741-756.

[37] Jones, P. G., VanBogelen, R. A., Neidhardt, F. C., J. Bacteriol. 1987, 169, 2092-2095.

[38] Haney, P. J., Badger, J. H., Buldak, G. L., Reich, C. I., Woese, C. R., Olsen, G. J., Proc. Natl. Acad. Sci. USA 1999, 96, 35783583

[39] Kumar, S., Tsai, C. J., Nussinov, R., Protein Eng. 2000, 13, 179-191.

[40] Price, C. W., Fawcett, P., Ceremonie, H., Su, N., Murphy, C. K., Youngman, P., Mol. Microbiol. 2001, 41, 757-774.

[41] Benson, A. K., Haldenwang, W. G., J. Bacteriol. 1992, 174, 749-757.

[42] Benson, A. K., Haldenwang, W. G., Proc. Natl. Acad. Sci. USA 1993, 90, 2330-2334.

[43] Boylan, S. A., Redfield, A. R., Brody, M. S., Price, C. W., J. Bacteriol. 1993, 175, 7931-7937.

[44] Volker, U., Voelker, A., Haldenwang, W. G., J. Bacteriol. 1996, 178, 5456-5463.

[45] Akbar, S., Gaidenko, T. A., Kang, C. M., O'Reilly, M., Devine, K. M., Price, C. W., J. Bacteriol. 2001, 183, 1329-1338.

[46] Dufour, A., Voelker, U., Voelker, A., Haldenwang, W. G., J. Bacteriol. 1996, 178, 3701-3709.

[47] Voelker, U., Voelker, A., Maul, B., Hecker, M., Dufour, A., Haldenwang, W. G., J. Bacteriol. 1995, 177, 3771-3780.

[48] Kang, C. M., Brody, M. S., Akbar, S., Yang, X., Price, C. W., J. Bacteriol. 1996, 178, 3846-3853.

[49] Yang, X. Y., Kang, C. M., Brody, M. S., Price, C. W., Genes Dev. 1996, 10, 2265-2275.

[50] Kang, C. M., Vijay, K., Price, C. W., Mol. Microbiol. 1998, 30, 189-196.

[51] Hughes, K. T., Mathee, K., Annu. Rev. Microbiol. 1998, 52, 231-286.

[52] Voelker, U., Dulfour, A., Haldenwang, W. G., J. Bacteriol. 1995, 177, 114-122.

[53] Smirnova, N., Scott, J., Voelker, U., Haldenwang, W. G., J. Bacteriol. 1998, 180, 3671-3680.

[54] Qi, Y., Hulett, F. M., J. Bacteriol. 1998, 180, 4007-4010.

[55] Haldenwang, W. G., Microbiol. Rev. 1995, 59, 1-30.

[56] Hecker, M., Volker, U., Mol. Microbiol. 1998, 29, 1129-1136.

[57] Wu, L. J., Errington, J., J. Bacteriol. 2000, 182, 418-424.

[58] Ito, M., Guffanti, A. A., Oudega, B., Krulwich, T. A., J. Bacteriol. 1999, 181, 2394-2402.

[59] Kosono, S., Ohashi, Y., Kawamura, F., Kitada, M., Kudo, T., J. Bacteriol. 2000, 182, 898-904.

[60] Switzer, R. L., Turner, R. J., Lu, Y., Prog. Nucleic Acid Res. Mol. Biol. 1999, 62, 329-367.

[61] Scott, J. M., Mitchell, T., Haldenwang, W. G., J. Bacteriol. $2000,182,1452-1456$

[62] Takami, H., Nakasone, K., Takaki, Y., Maeno, G., Sasaki, R., Masui, N., Fuji, F. et al., Nucleic Acids Res. 2000, 28, 43174331.

[63] Gusarov, I. I., Kreneva, R. A., Podcharnniaev, D. A., Iomantas, I. V., Akalakina, E. G., Stoinava, N. V., Perumov, D. A., Kozlov, I. I., Mol. Biol. 1997, 31, 446-453. 
[64] Lee, J. M., Zhang, S., Saha, S., Anna, S. S., Jiang, C., Perkins, J., J. Bacteriol. 2001, 183, 7371-7380.

[65] Bresler, S. E., Cherepenko, E. I., Chernik, T. P., Kalinin, V. L., Perumov, D. A., Genetika 1970, 6, 116-124.

[66] Bresler, S. E., Cherepenko, E. I., Perumov, D. A., Genetika 1970, 6, 126-139.

[67] Glazunov, E. A., Bresler, S. E., Perumov, D. A., Genetika 1974, $10,83-92$.
[68] Bresler, S. E., Glazunov, E. A., Perumov, D. A., Chernik, T. P., Genetika 1977, 13, 2007-2016.

[69] Bresler, S. E., Gorinchuk, G. F., Chernik, T. P., Perumov, D. A., Genetika 1978, 14, 2082-2090.

[70] Grundy, F. J., Henkin, T. M., Mol. Microbiol. 1998, 30, 737749. 